I long ago sold my Whitman editions, but I display the Gutekunst portrait where I can see it every day. I am grateful to Ed Folsom and the Walt Whitman Quarterly Review for allowing me to share it with you.

\title{
AM I NOT A MAN AND A POET?: A RECENTLY RECOVERED WHITMAN CARICATURE
}

The February 27, 1869, issue of Punch, Victorian England's premier satirical rag, features a previously undocumented article on Walt Whitman entitled "He is a Man." Punch, edited at the time by Mark Lemon (who co-founded the periodical along with Henry Mayhew), takes this opportunity to contradict painter and Atlantic Monthly art critic Eugene Benson, who claimed that, "[w] henever [Whitman] speaks, you hear the voice of a man in his agony, in his gladness, in his transports." Benson's rhapsodic praise of the American poet appears in his essay "Charles Baudelaire, Poet of the Malign" published in the same February 1869 issue of the Atlantic, where Whitman's "Proud Music of the Sea-Storm," ultimately titled "Proud Music of the Storm," was first printed. ${ }^{1}$ Punch's "He is a Man" reprints reactions to Benson's comments on Whitman from two other periodicals-Theodore Hagen's New York Weekly Review ${ }^{2}$ and Britain's preeminent music journal, Musical World, ${ }^{3}$ then edited by James William Davison. Accompanying the text of "He is a Man" is the racist caricature of a black male having his forehead shined and/or blackened while reclining on a sidewalk — an image entirely of Punch's own invention.

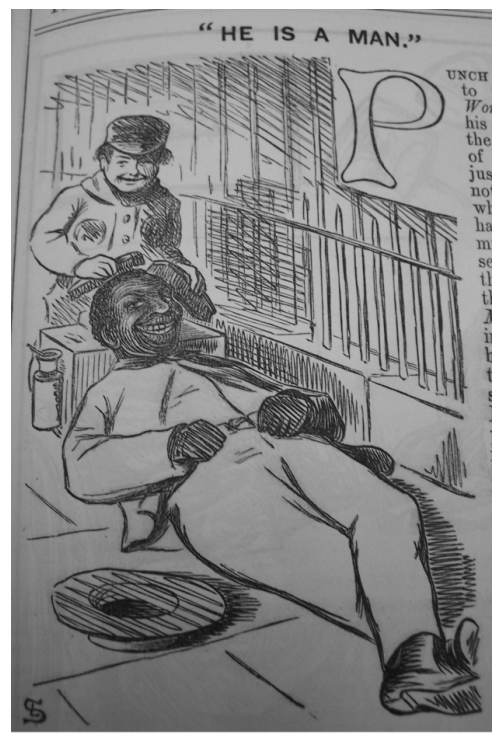

Punch-whose comedic affect Martha Banta describes as a merger of "cheeky, Cockney irreverence" and "sanctified British tradition" - had previously dismissed Leaves of Grass as proof that the "fields of American literature" needed "weeding dreadfully." Published thirteen years after this initial critique, "He is a Man" marks Punch's return to transatlantic Whitman-bashing. ${ }^{6}$ Punch begins its 1869 attack on Whitman by thanking Musical World for the opportunity to lampoon "such trash":

Punch is indebted to the Musical World for calling his attention to the following bit of keenness and justice. He did not see, at first, what the topic had to do with music; but, on second thoughts, the wisdom of the editor of the $M . W$. in extracting the passage became evident - those who praise such trash as Mr. Whitman's perform on the instrument called Fiddle-faddle, which the $M . W$. has of course a right to criticise:- 
After these prefatory remarks, Punch includes an excerpt from the January 23, 1869, Weekly Review, which responds to Benson's reading of Whitman. The excerpt transcribed below is taken from the Weekly Review; the article was reprinted by Musical World and Punch, but all specific references to "Proud Music" were removed. The following is a full transcription of the Weekly Review's original comments on Whitman; the portion alluding to "Proud Music" (two sentences not reprinted by Punch or Musical World) appears in brackets below:

[Several pages of the February Atlantic occupied by a catalogue, couched in fantastic prose, of various sounds, musical and other, which have been heard by Mr. Walt Whitman, partly in the flesh and partly in the spirit. A first-class puff of Alboni, who is called "the teeming lady," is introduced into this "document in madness," and Lord Byron's "banner torn but flying," is used without credit.] In another part of the same magazine, the reader is told that whenever Mr. Walt Whitman speaks, "you hear the voice of a man." The fact that Mr. Whitman is "a man," ought to be pretty well understood by this time, considering the strenuous emphasis and minute particularity with which Mr. Whitman himself has described his physical attributes, to say nothing of the stress which his critical admirers have laid upon his virility. In truth, many readers of current magazine literature are getting a little tired of hearing about $\mathrm{Mr}$. Whitman's physique, especially as associated with the new doctrine that muscle is genius. Could it not be agreed, all round, once for all, that Mr. Whitman is "a man," and a very large and heavy one, so that the topic may be set at rest? Its disappearance from the field of literary discussion would be a great relief. The statement that $\mathrm{Mr}$. Whitman is a poet, would still remain for controversy, and surely that is sufficiently exasperating, in view of the copious catalogues, suggestive of nothing so much as a crazy auctioneer, which Mr. Whitman continues to publish under the name of poetry.

\section{Following this extract, Punch concludes:}

If the $M . W$. sees any more such good bits, we shall be glad to read them in its pages, which we observe lately have become replete with a serener wisdom than of yore. Perhaps RABELAIS was a little over the heads of the majority of musical folk. ${ }^{7}$ Still, Punch hopes it will occasionally lend the good service due from all educational journals towards demolishing Shams, whereof there is no greater than MR. WHITMAN-we say it, even at the risk of bringing on an American War.

The article itself makes no direct connection to the accompanying illustration by Lindley Sambourne, one of Punch's premier artists. ${ }^{8}$ And as a result, it remains ambiguous whether or not the reclining black figure is intended to represent Whitman. But if we read the black male in Punch's caricature as Whitman, Sambourne implies that the poet is the greatest "Sham" because he has falsely represented himself as a white man. Through similarities in costuming and posture, Punch's caricature plays off Whitman's famous Bowery b'hoy pose for the 1855 frontispiece, and, to this end, Sambourne's image agrees that Whitman is both a rough and a loafer. ${ }^{9}$ In contrast to the iconic frontispiece image, Sambourne has removed the poet's characteristic hat. This 
subtle alteration enacts the process of exposure described in "He is a Man" by fully disclosing the figure's face to the reader's gaze: he is not the virile white man depicted in the 1855 frontispiece (an image which became more widely circulated in Britain when its truncated incarnation appeared in the 1868 English edition of Whitman's work), but a slothful black man instead. ${ }^{10}$ Both Whitman and the caricatured black male, Punch suggests, inadvertently expose themselves as shams through the transparency of their inept performances. In his naïve attempt to mimic middle-class respectability, Sambourne's figure has his head polished, not his shoes; Whitman, hoping to pass off Leaves of Grass "under the name of poetry," merely produces "copious catalogues." The dissonance between Whitman's pretensions and his literary productions was all too apparent for Punch. Over twenty years later, with Whitman wellestablished as the Good Gray Poet, Punch again turns a suspicious eye towards Whitman's poetic posturing, warning readers: "Don't be taken in and accept W.W. at his own poetic valuation as a poet, simply because he is wrinkled, old, white-haired, and wears a venerable look, which, after all, may be only a hypocritical mask." 11 With this in mind, Sambourne's black Whitman seems to be an earlier and cruder attempt to expose just such a "hypocritical mask."

In Sambourne's illustration, the poet's physical blackness, whether it be natural or applied by a shoe-shine boy, contradicts the visual identity Whitman constructs at the beginning of the first American and English editions of his poetry. Though Whitman's frontispiece helped him establish at least a tenuous physical (and Caucasian) persona as "Walt Whitman, an American, one of the roughs, a kosmos," the identities Whitman forged in print were far more protean than this single iconic image might suggest. As Kenneth Price has demonstrated, much of Whitman's textual persona is built on racial crossings, some of which are direct (as when Whitman embodies "the hounded slave"), others indirect-latent in Whitman's persistent challenge to a white, male, middle-class and Boston-centered American literary identity. ${ }^{12}$ For a bourgeois journal like Punch, the inspiration to cast Whitman in blackface is, as Price notes, already present in Whitman's repeated exploration of "cross-racial identifications"(11). But as exemplified by Punch, reviewers often turned these frequent transformations in Whitman's poetic persona, a technique so central to the experimental poetics of Leaves of Grass, against him. Sambourne's caricature is one of several critical attempts to undermine Whitman's status as a poet through racially charged depictions of him as "a sexual, religious, and even subhuman outsider" (10). And Punch is not alone-not even in the history of Whitman's reception in England. In fact, another English journal, the London Critic, went so far as to characterize Whitman as the half-human slave Caliban "flinging down his logs, and setting himself to write a poem."13 While Punch may be the first periodical to illustrate a black Whitman, there was precedent for employing racial stereotypes to dismiss Whitman as a "poet."

Certainly Punch's black Whitman alludes to the most recognizable image of the poet available by 1869 - the 1855 frontispiece - but by depicting Whitman as a black male, Punch may also be reacting to the radical identity shifts Whitman enacts throughout the poetry of Leaves of Grass. Trading on common nineteenth-century stereotypes, this caricature locates in the black body two 
traits for which Whitman was often criticized: his tendency to lean and loaf and his unabashed sexuality. ${ }^{14}$ Sambourne's image marries the stereotype of the lazy and lustful black male with Whitman's own self-styled poetic persona. Benson's original comment from the Atlantic is shortened over the course of the three periodical reprintings, but his original claim that, "Whenever [Whitman] speaks, you hear the voice of a man in his agony, in his gladness, in his transports," also carries distinct sexual connotations. Whitman "in his agony" not only embodies the "hounded slave's" physical sufferings, but he is also the poet in the throes of orgasm, the voice of "libidinous prongs."

Benson's claim to Whitman's masculinity ('man' as male) is simultaneously an expression of the poet's humanity ('man' as human). When Punch recontexualizes Benson's appraisal of Whitman's masculine voice as the heading of a racist caricature, it ironically echoes two phrases circulating in Britain by the late 1860's: Abraham Lincoln's rumored reaction to seeing Whitman in 1864 ("Well, he looks like a man!") and the slogan popularized during the British abolition movement, "Am I Not a Man and a Brother?" Lincoln's supposed remark dates back to a July 30, 1865, letter to Whitman from A. Van Rensallaer, in which he recalls a conversation with the President. According to Van Rensallaer, Lincoln made the comment about Whitman after watching the poet stroll past a White House window. The anecdote made its way into several reviews of Whitman's work on both sides of the Atlantic; William Michael Rossetti even quotes Lincoln in the preface to the first English edition of Whitman's poetry. ${ }^{15}$ By 1869, England was familiar with Lincoln's thoughts on slaves and on Whitman - to the Great Emancipator both were indeed men. Sambourne's caricature may allude to Lincoln, then, lampooning the President's vision and suggesting neither Whitman nor the black male are truly men.

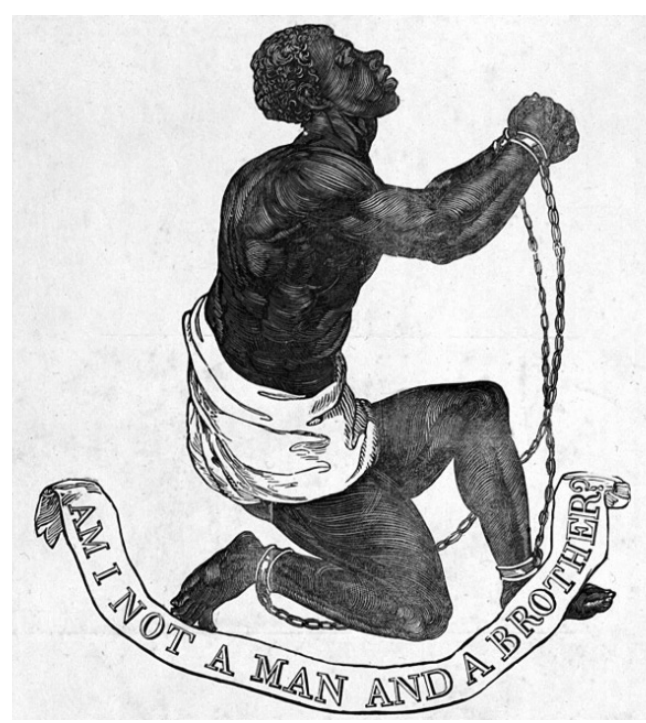

Punch also satirizes the abolitionist cause more broadly, offering Sambourne's caricature as its own response to the question "Am I Not a Man and a Brother?" The phrase was made famous by Quaker Josiah Wedgwood; as a member of the Society for Effecting the Abolition of the Slave Trade, he created a seal depicting a kneeling African in chains under which the appeal for human treatment was inscribed. As Adam Hochschild has shown, "Am I Not a Man and a Brother" was "probably the first widespread use of a logo designed for a political cause." 16 Wedgwood's design was ubiquitous; it appeared "everywhere from books and leaflets to snuffboxes and cufflinks." Eventually, the image 
also became popular in America - in 1835 it was printed on the same broadside as John Greenleaf Whittier's poem, "My Countrymen in Chains!"

As a satiric appropriation of the abolitionist insignia, Sambourne's caricature intentionally undercuts the values that inform Wedgwood's seal. Wedgwood's figure is supplicant, spiritual and desexualized; viewers are denied access to the crotch that Whitman's frontispiece and Sambourne's image make so central to their compositions. Indeed, the slave's impassioned plea in Wedgwood is transformed in Sambourne to sloth and grinning complacency. Given that Britain had outlawed slavery in 1833, the fact that a black man was both a man and a brother "ought to [have been] pretty well understood" by 1869 . However, Punch's caricature is undoubtedly a challenge to such assertions of equality. Whatever we take Punch to imply about the status of the black subject's manhood, the image and caption absolutely deny the possibility of his brotherhood. "Even at the risk of bringing on an American War," Sambourne's caricature delivers this ignominious punch-line: Whitman's status as a 'poet' is as laughable as the black man's pretentions to humanity and equality.

The University of Iowa

ERIC CONRAD

\section{NOTES}

1 Eugene Benson, "Charles Baudelaire, Poet of the Malign," Atlantic Monthly (February 23, 1869), 171-177; Walt Whitman, "Proud Music of the Sea-Storm," Atlantic Monthly 23 (February 1869), 199-203.

2 “Editorial Miscellany," New York Weekly Review (January 23, 1869), 5. Whitman's name would have been familiar to the Weekly Review. Two of the poet's fellow regulars at Charles Pfaff's beer cellar in lower Manhattan - theater critic and essayist Charles Bailey Seymour and former editor of the Saturday Press and long-time Whitmansupporter Henry Clapp Jr.- - both wrote for Hagen's journal in the late 1860s.

3 “Provincial," The Musical World (February 13, 1869), 105.

4 Martha Banta, Barbaric Intercourse: Caricature and the Culture of Conduct, 1841-1936 (Chicago: University of Chicago Press, 2003), 64.

5 “A Strange Blade," Punch (April 26, 1856), 169.

6 The August 22, 1868 Punch does make notice of one "Mr. Watt [sic] Whitman, who scorns the vulgar trammels of rhyme and rhythm to which his predecessor is a slave, and also those of decency, which ignobly bind the majority of mankind" (86). Whitman himself was at least a reluctant admirer of Punch's cutting humor, once observing "There is some dry wit yet in London Punch" (NUPM, 1:137). In another notebook entry, Whitman alludes to Punch to describe the "English Masses": "The large mass (nine tenths) of the English people, the peasantry, laborers, factory-operatives, miners, workers in the docks, on shipping, the poor, the old, the criminals, the numberless flunkies of one sort and another, have some of the bull-dog attributes but are generally minus the best attributes of humanity. They are not a race of fine physique, or any spirituality, or manly audacity, - have no clarified faces, candor, freedom, agility, and quick wit.-They are short, have mean physiognomies, (such as are in the caricatures in 'Punch')" (NUPM, 5:1986). 
7 In "A Peg for Some Pleasant Pegging” (Punch [April 15, 1865], 155), Punch characterizes Musical World as displaying "Rabelaisian inscrutabilities" which "though heinously defiant of mundane intellect, are usually of a genial and kindly sort."

8 Lindley Sambourne was one of Punch's main Big Cut artists. For further discussion of Sambourne's racial caricatures see Banta's analysis of his depictions of the Zulu monarch Cetewayo in 1882 and 1883 issues of Punch (34-37).

9 Punch's 1856 critique of Whitman was used to preface a similar attack on the poet in the Christian Examiner. In a review that Whitman reprints in Leaves of Grass Imprints, the Christian Examiner references Punch's "sarcastic allusion" to Whitman in "A Strange Blade" and adds its own appraisal of Leaves of Grass, calling it one of American literature's "worst disgraces." The reliability of Whitman's print identity is scrutinized by the Christian Examiner: "Whether or not the author really bears the name he assumes, - whether or not the strange figure opposite the title-page resembles him, or is even intended for his likeness - whether or not he is considered among his friends to be of sane mind,- - whether he is in earnest, or playing off some disgusting burlesque,-we are hardly sure yet" (Imprints, 6).

10 For a discussion of the sexual undertones in 1855 frontispiece (and their suppression in the English edition of Whitman's poetry edited by William Michael Rossetti and published by John Camden Hotten), see Ted Genoways, "One goodshaped and wellhung man': Accentuated Sexuality and the Uncertain Authorship of the Frontispiece to the 1855 Edition of Leaves of Grass," in Susan Belasco, Ed Folsom, and Kenneth M. Price, eds., Leaves of Grass: The Sesquicentennial Essays (Lincoln: University of Nebraska Press, 2007), 88-123.

11 "Give it to the Bard!", Punch (November 1, 1890), 215.

12 See Kenneth M. Price's chapter "Whitman in Blackface" in To Walt Whitman, America (Chapel Hill, North Carolina: University of North Carolina Press, 2004), 9-36.

13 See the Critic (April 1, 1856), 170-171.

14 Commenting on Punch's treatment of blacks more broadly, Banta writes: "In the 1840 s and 1850 s, nigger . . . was in common currency in Punch's pages, at the same time as it rebuked Uncle Sam for holding on to his nation's slaves. Long after the American Civil War, Punch made comic material out of coon songs, supplemented with asides about wogs, fuzzy-wuzzys, and Zulu beauties, even as it chided the United States for condescending behavior towards blacks" (189).

15 Rossetti's preface praises Whitman, Lincoln, and "When Lilacs Last in the Door-yard Bloom'd“ (15). For other references to Lincoln's comment on Whitman, see Robert Buchanan, "Walt Whitman," The Broadway (November 1867), 188-195; "Walt Whitman's Poems," The London Sun (April 17, 1868), 31490; William Douglas O’Connor, The Good Gray Poet.

16 Adam Hochschild, Bury the Chains: Prophets and Rebels in the Fight to Free an Empire's Slaves (Boston: Houghton Mifflin, 2005), 128. 